Article

\title{
Dynamic Impacts of Economic Growth and Forested Area on Carbon Dioxide Emissions in Malaysia
}

\author{
Rawshan Ara Begum *, Asif Raihan $(\mathbb{D}$ and Mohd Nizam Mohd Said $(\mathbb{D}$ \\ Institute of Climate Change (IPI), Universiti Kebangsaan Malaysia (UKM), Bangi 43600, Selangor, Malaysia; \\ asifraihan666@gmail.com (A.R.); m.n.said@ukm.edu.my (M.N.M.S.) \\ * Correspondence: rawshan@ukm.edu.my
}

Received: 17 September 2020; Accepted: 26 October 2020; Published: 11 November 2020

\begin{abstract}
This study measures the relationship and dynamic impacts of economic growth and forested area on carbon dioxide $\left(\mathrm{CO}_{2}\right)$ emissions in Malaysia. Time series data over the period of 1990 to 2016 were used by employing the dynamic ordinary least squared (DOLS) approach. The results of DOLS estimation indicate that the coefficient of economic growth is positive and significant with $\mathrm{CO}_{2}$ emissions, meaning that RM1 million increase in gross domestic product (GDP) is associated with an increase in $\mathrm{CO}_{2}$ emissions of 0.931 kilo tons. Instead, the long-run coefficient of forested area found negative and significant, which implies that declining one hectare of forested area (i.e., deforestation) has an impact of three kilo tons of $\mathrm{CO}_{2}$ emissions rise in Malaysia. Our study findings indicate that economic growth and deforested area have an adverse effect on Malaysia's carbon emissions where GDP growth fosters carbon emissions at a faster rate. Thus, the effective implementation of policy measures and economic instruments including afforestation and reforestation, forest conservation, sustainable forest management, REDD+ (reducing emissions from deforestation and forest degradation plus) mechanism and other emission reduction mechanisms inter alia could be useful for reducing carbon emissions while decreasing deforestation and maintaining the long-term economic growth in Malaysia.
\end{abstract}

Keywords: forests; deforestation; emissions; economy; DOLS; Malaysia

\section{Introduction}

Over the 21st century, atmospheric accumulation of greenhouse gases (GHGs) has become a major concern due to climate change. $\mathrm{CO}_{2}$ is the dominant GHG which is emitted mainly from human induced activities like burning of fossil fuels and deforestation. Since the industrial revolution from the agricultural sector, $\mathrm{CO}_{2}$ emissions from deforestation and forest degradation have been growing rapidly which is one of the main reasons for the global climatic system changing. Anthropogenic land use change together with deforestation and forest degradation contributes about one-fifth of the global annual $\mathrm{CO}_{2}$ emissions, which was $0.9 \mathrm{Gt}$ per year [1]. About 10,000 years ago, $45 \%$ of the total land surface in the world was covered by the forests, around six billion hectares. However, shrinkage of global forest cover has been continuing from that period and it turned into only about $31 \%$ in 2010 [2]. Global forest cover has been changing rapidly over the past few decades where the forest cover in tropical regions has reduced significantly by an annual reduction of 2101 square kilometers per year [3]. Over the last few decades, there has been no significant changes of the net carbon emission annually from deforestation [4]. According to Hansen et al. [3], almost 2.3 million square kilometers of global forest land were lost within 2000 and 2012, while only 0.8 million square kilometers of forest were gained in this time period.

However, forests in tropical regions cover around $7-10 \%$ of the total land area in the earth which is also $13 \%$ of the total vegetation area around the globe [5,6]. Houghton [4] reported that $1.4 \pm 0.5$ PG 
(petagrams) of carbon are emitted per year over the period of 1990 to 2010 because of deforestation and forest degradation in tropical regions. Due to excessive $\mathrm{CO}_{2}$ emission from deforestation, massive impacts from climate change have occurred in Malaysia, which is also one of the leading $\mathrm{CO}_{2}$ emitters among the south-east Asian countries. Malaysia's development and economic growth activities also lead to increasing carbon emissions from land clearing and conversion of the forested land to other economy-based land use activities such as agriculture, settlement, mining, fish farming, etc. [7]. While economic development enhances societal prosperity, it also has an environment cost [8,9]. For instance, forest degradation including non-forestry land uses (i.e., timber harvesting for agricultural land conversion) releases huge carbon into the atmosphere $[9,10]$. Though the natural resources are limited and exhaustible, still those are used as inputs for production and development processes. Hence, it is difficult to reduce environmental degradation until the functional relationship between natural resources and economic development processes changes [11,12]. These problems are very common, and the risks are higher in the developing countries like Malaysia, where the relations among economic growth, forests and sustainability are critical.

The environmental impact resulting from economic growth is crucial because any economy usually functions for maximising economic growth [13-15]. Nevertheless, a number of research and studies presented empirical evidence which investigated the dynamic relationship between environmental quality and economic growth in different developed and developing countries. During the past two decades, several studies showed the relationships between $\mathrm{CO}_{2}$ emissions and its determinants such as economic growth and energy consumption [15-25]. However, the Intergovernmental Panel on Climate Change (IPCC) reported that land use, land-use change, and forestry contributed around $17 \%$ of the annual global GHG emissions [1]. Instead, the forestry sector also plays a significant role in climate change mitigation and sustainable green economy [26]. Nabuurs et al. [27] estimated that that EU forestry sector currently produces an overall climate mitigation impact that amounts to about $13 \%$ of the total EU emissions. Nevertheless, there is a limited study which specifically investigates the dynamic impact between forested area and $\mathrm{CO}_{2}$ emissions. Though the deforestation rate is higher in developing countries like Malaysia, the specific research on the dynamic impacts of economic growth and forested area on $\mathrm{CO}_{2}$ emission is lacking. Thus, this article attempts to analyse the dynamic impacts of economic growth and forested area on $\mathrm{CO}_{2}$ emission in Malaysia by applying these impacts and their relations, employing the dynamic ordinary least squared DOLS approach. The findings of this study would provide better understanding between the interactions of the environment (i.e., carbon emissions, forests and economic growth) towards achieving sustainable development.

\section{Forests and Deforestation in Malaysia}

Forests play a key role in keeping the balance of the global climatic system by absorbing and storing atmospheric carbon, maintaining hydrological systems, conserving biodiversity and providing habitats for the wildlife. Forests in Malaysia are categorised by three types of forests which are protected forests, permanent reserved forests and state land forests. Figure 1 shows the graphical trend of total forest land in Malaysia. In 1990, total forest land was about 18.8 million hectares, dropping to 17.9 million hectares in 1993 and rising again with 18.47 million hectares in 1997. In 1999, the trend shows downward again, and the total forest land declined to 17.68 million hectares (ha) in 2008 . One of the main reasons for this reduction of forest land might be deforestation and forest degradation due to excessive logging and development activities. Between 1990 and 2010, Malaysia lost around 0.86 million ha of forest cover (i.e., $4.23 \%$ of its total forest land). The long history of logging activities means there are degraded areas that could be reforested for forest conservation, ecosystem services and carbon sequestration. Since 2009, the total forested areas in Malaysia have been on an upward trend due to some programmes and activities through afforestation, reforestation, forest protection and conservation; thus, the total forest land became 18.4 million ha in 2016. It is remarkable that the area of protected forest land in Malaysia was 1.44 million hectares in 1990 but by the end of 2014, it was 2.76 million hectares, almost doubled in 24 years [28]. Protected forests play a significant role 
in ecosystem and biodiversity conservation [29]. This indicates a huge potential of climate change mitigation by increasing forest protection and conservation in Malaysia.

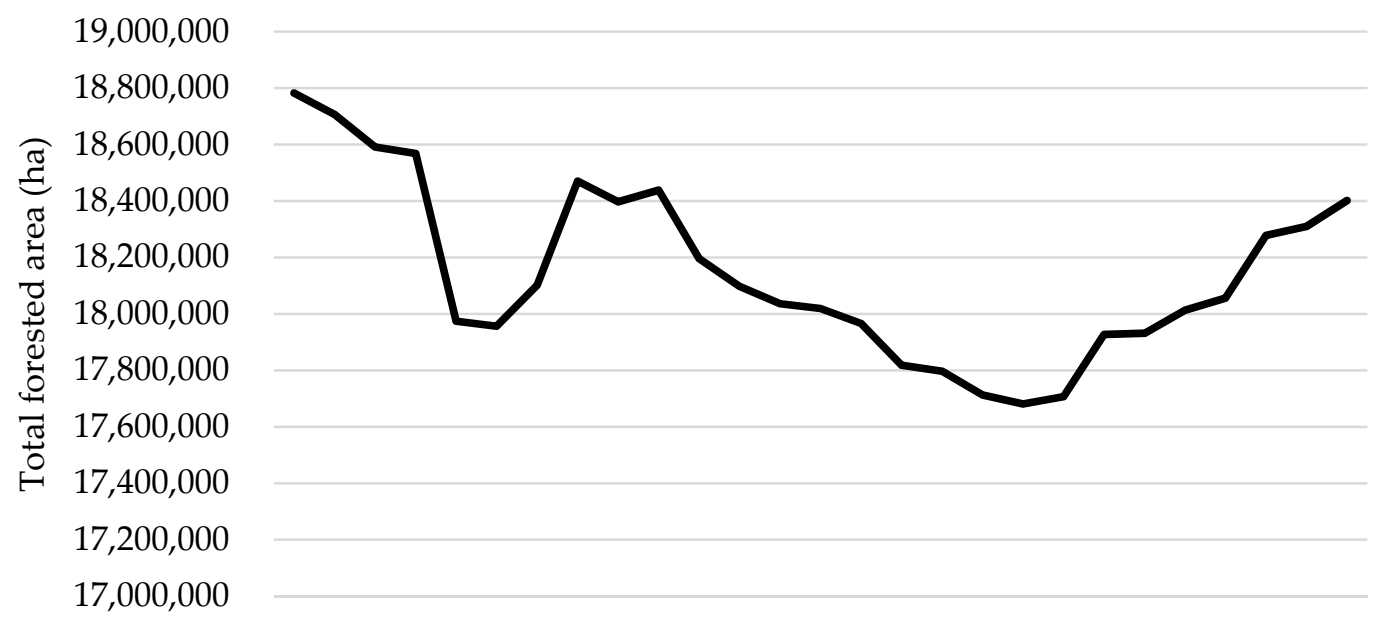

19901992199419961998200020022004200620082010201220142016

Year

Figure 1. Annual trend of total forest land in Malaysia [data sourced from [28]].

However, Malaysia had a severe rate of deforestation between 1990 and 2010 that is $8.6 \%$ of its forest cover, or about 1.92 million ha. This might be due to primarily from industrialisation, urbanisation, settlements, mining, farming, agricultural fires, clearing forest for oil-palm plantations and other forms of agriculture. According to Jomo et al. [30], Sarawak had lost 50\% of its forest cover whereas Peninsular Malaysia shrunk to about half of its original forests from 1971 and 1989. Osman et al. [31] reported that more than 1.85 million ha of forests in Sabah were lost (i.e., approximately $50 \%$ of Sabah's total forest cover) from 1990 to 2008 due to the expansion of commercial plantations. Table 1 presents the deforestation rate of total and natural forest cover in Malaysia from 1990 to 2010. The loss of forest cover in Malaysia is quite alarming, and it has been reported that the annual deforestation rate of Malaysia increased nearly 86\% from 1990 to 2005 [2]. Malaysia lost an annual average of 1.4 million hectares ( $0.65 \%$ ) of its forest area from 2001 to 2005, whereas total deforestation declined from 2006 to 2010. Presumably, old-growth natural forests were the main type of forests that were deforested, resulting in greater $\mathrm{CO}_{2}$ emissions as they hold higher concentrated amount of carbon. According to IPCC [1], deforestation and forest degradation is the second major source of $\mathrm{CO}_{2}$ emissions. In Malaysia, the land use, land-use change, and forestry (LULUCF) sector also causes $\mathrm{CO}_{2}$ emissions while contributing a major source of carbon biomass and sequestration. For instance, large tracts of tropical forests have been deforested and converted to agricultural land and settlements due to increasing human population and their anthropogenic activities [7]. Therefore, reducing $\mathrm{CO}_{2}$ emissions has become a major concern all over the globe to maintain environmental sustainability and to minimise the negative impacts of climate change [32].

Table 1. Deforestation rate in Malaysia * [2].

\begin{tabular}{ccccc}
\hline Years & \multicolumn{2}{c}{ Total (Net) Forest Cover Change (Per Annum) } & \multicolumn{2}{c}{ Natural Forest Cover Change (Per Annum) } \\
\hline & $\mathbf{1 0 0 0}$ ha & Percent & $\mathbf{1 0 0 0}$ ha & Percent \\
\hline $1990-2000$ & -79 & -0.36 & -49 & -0.2 \\
$2001-2005$ & -140 & -0.66 & -49 & -0.24 \\
$2006-2010$ & -87 & -0.42 & -128 & -0.64 \\
\hline
\end{tabular}

${ }^{*}$ Negative signs reflect deforestation. 


\section{Economic Growth and Carbon Emission in Malaysia}

Southeast Asia demonstrates how globalisation plays a role in changing forestry patterns, value-chains and trade, from the 1960s to the present. Since the last two decades, it is apparent that deforestation is linked with globalisation, international business and growing cash crops [33]. Malaysia is one of the world's fastest growing economies since the 1970s [34]. Within a very short time, per capita income has doubled in Malaysia as it is a leading exporter of manufactured goods and primary commodities. Malaysia's forest resource utilisation led to its socio-economic development, resulting in Malaysia becoming the world's leading exporter of tropical timber products, oil palm, rubber, cocoa, pepper, pineapple and tobacco [35-38]. In this regard, Figure 2 shows the forestry sector's contribution to Malaysia's gross domestic product (GDP) in percentage. In 1973, a large percentage of Malaysia's GDP (i.e., about 32\%) came from the forestry sector and their activities, whereas in 2017 it declined to only 1.8\%. This indicates that the dependency of Malaysia's GDP shifted to industrial and service sectors, and away from the forestry sector. Therefore, sustainable management of forest resources is important to ensure a potential contribution to Malaysia's future economic growth and long-term socio-economic development [39].

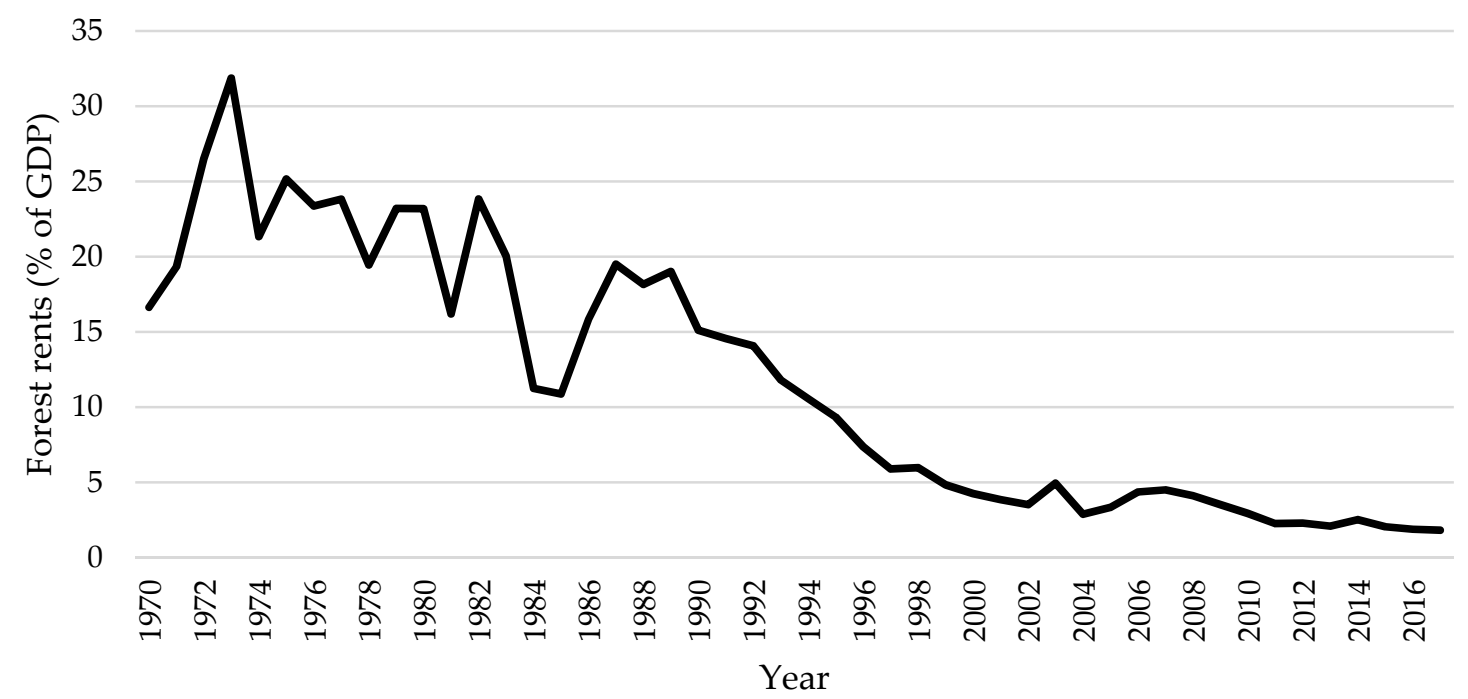

Figure 2. Forestry sector's contribution to gross domestic product (\%) in Malaysia [40].

Nevertheless, Malaysia experienced the average economic growth of about $7.7 \%$ and $5.8 \%$ within the period 1970-1980 and 1980-1990, respectively. The average economic growth within the period 1990 to 2005 was above $6.5 \%$. There are many factors that can contribute to the growth rate of an economy [41]. Since 1990, Malaysia's economic growth decreased only in 1998 due to the Asian financial crisis, and again declined between 2008 and 2009 during the global economic recession. In the meantime, rapid transformation occurred in the agriculture-based economy in Malaysia, which turned into industrialisation. Because of urbanisation, industrialisation and population expansion, $\mathrm{CO}_{2}$ emissions in Malaysia increased drastically as a consequence of deforestation and forest degradation. The amount of $\mathrm{CO}_{2}$ emissions in 2007 was about 7.32 tons per capita in Malaysia while the global average $\mathrm{CO}_{2}$ emissions was only 4.63 tons per capita [40]. Figure 3 presents the per capita GDP (RM 1000) and $\mathrm{CO}_{2}$ emissions (tons per capita) in Malaysia. In 1960, per capita GDP and $\mathrm{CO}_{2}$ emissions were RM4824 and 0.44 tons which turned to RM40,063 and 8.09 tons in 2016, respectively. However, per capita GDP and $\mathrm{CO}_{2}$ emissions rise over the time while GDP growth indicates a steady linear trend. 


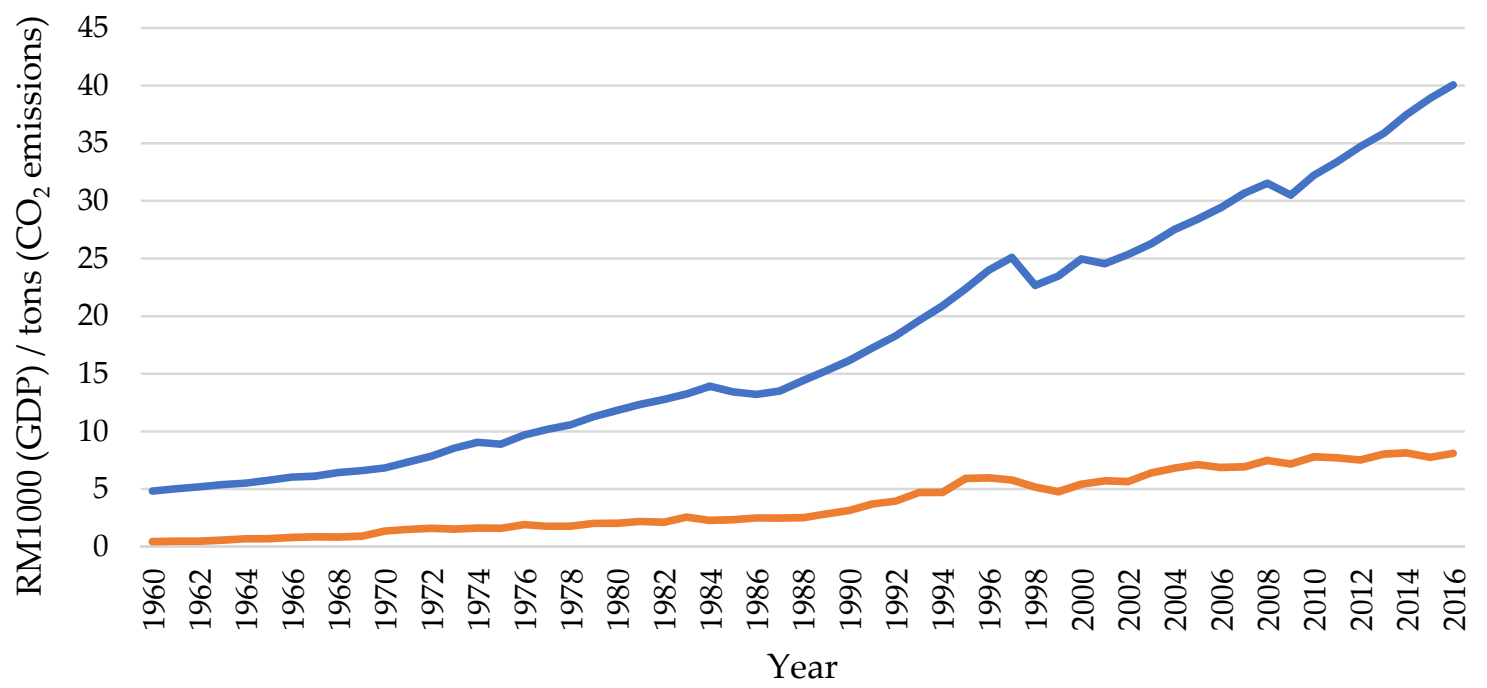

$\longrightarrow$ GDP per capita (RM1000) $\longrightarrow \mathrm{CO}_{2}$ emissions (tons per capita)

Figure 3. Per capita GDP (RM1000) and $\mathrm{CO}_{2}$ emissions (tons) in Malaysia [40].

On the other hand, the climate change performance index for Malaysia is quite low, ranked 53rd among the most polluted 61 countries [42]. Furthermore, the average annual growth rate of $\mathrm{CO}_{2}$ emissions in Malaysia was recorded as 4.6\% for the period of 1971 to 2012. It is also apparent from Figure 2 that per capita GDP and $\mathrm{CO}_{2}$ emissions have augmented significantly over the time. In the last two decades, Malaysia has initiated its national vision policy and economic transformation policy that concentrated on stimulating economic growth and achieving the 2050 vision while implementing intensive economic development with clean environment and sustainability. There exists some constraints and gaps in several GHG emitting economic sectors such as technical and capacity gaps [43]. Hence, Malaysia is one of the few developing countries that recognised the positive contribution of a clean environment on economic development by identifying and implementing various mitigation measures as a part of the framework for development process [44]. However, Malaysia's forestry sector has attracted dual interests to reduce GHG emissions while contributing to the national economy. For instance, tourism activities in Malaysian forests and national parks generate employment and economic activity which ultimately accelerate the national economy [45].

\section{Methodology}

The facts and figures shown in the previous sections provide a basic understanding of the relationship between forests, economic growth and $\mathrm{CO}_{2}$ emission in Malaysia. Thus, this study investigated an empirical analysis of the dynamic impacts of economic growth and forested area on $\mathrm{CO}_{2}$ emissions in Malaysia by using the dynamic ordinary least squared (DOLS) approach of cointegration by Pesaran and Shin [46] and Pesaran et al. [47]. Variables were measured in kilo tons for $\mathrm{CO}_{2}$ emissions, 1 million Ringgit Malaysia for real GDP and hectares (ha) for forested area. Time series data from 1990 to 2016 for Malaysia was used based on the World Development Indicator (WDI) dataset.

This study considers $\mathrm{CO}_{2}$ emissions (here after carbon emissions) as dependent variable. Since Grossman and Krueger [12] suggest that economic growth and $\mathrm{CO}_{2}$ emissions follow a non-monotonic relation, this study considers GDP in the research framework. Forests play a very important dual role for $\mathrm{CO}_{2}$ emissions. Forests and their tree biomass absorb and store the atmospheric $\mathrm{CO}_{2}$, which is also called carbon sequestration, while due to deforestation/tree cutting, $\mathrm{CO}_{2}$ is released into the atmosphere. As deforestation is one of the main causes of $\mathrm{CO}_{2}$ emissions contributed to by Southeast Asia or Malaysia, this study attempts to show their causal relationship by employing 
econometric analysis. Therefore, this study considers annual forested area (FA) as one of the regressors that was collected from the Ministry of Natural Resources and Environment (MNRE), Malaysia. In addition, time series data for economic growth (i.e., GDP in constant local currency unit (million $\mathrm{RM}$, million Ringgit Malaysia)) and $\mathrm{CO}_{2}$ emissions (kilo tons, $\mathrm{kt}$ ) were obtained from the WDI dataset. To analyse the time series data, this study applied DOLS, an expanded equation of ordinary least squares estimation. It includes explanatory variables as well as leads and lags of their first difference terms to control endogeneity and to calculate the standard deviations using a covariance matrix of errors which is robust to serial correlation. Inclusion of leads and lags of the difference terms approves that error term is orthogonalised. In addition, the Granger causality Wald tests are used to justify the lagged variables and identify the causality between the variables.

The DOLS estimators have a normal asymptotic distribution and their standard deviations provide a valid test for the statistical significance of the variables [19]. The DOLS approach is efficient in the occurrence of a mix order of integration, enabling integration of the individual variables in the cointegrated outline by estimating the dependent variable $\left(\mathrm{CO}_{2}\right.$ emissions in $\left.\mathrm{kt}\right)$ on explanatory variables (annual forested area in hectare and GDP in million RM) in levels, leads and lags. The justification for estimating DOLS model and variables used is described below.

Adopting a standard Cobb-Doglus production function assuming constant rate of returns, the aggregate output function can be shown at time, $t$ as follows:

$$
Y_{t}=F\left(K_{t}, A L_{t}\right)
$$

where $Y_{t}$ is GDP, $K_{t}$ is capital and $A L_{t}$ is effective labour. Presumably, carbon emissions arise due to the production function and economic activities, thus, emission function can be followed as:

$$
\mathrm{CO}_{2}(\mathrm{t})=\mathrm{v}(\mathrm{F}(\mathrm{Y}(\mathrm{t})))
$$

where $\mathrm{v}$ denotes the certain rate of $\mathrm{CO}_{2}$ emission due to the production function.

Not all forms of capital are responsible for carbon emissions, while energy usage such as oil, coal, gas and electricity primarily cause emissions discharge. Therefore, total capital can be consisted of emitting $\left(K_{e}\right)$ and non-emitting $\left(K_{n}\right)$ capitals as shown below:

$$
\mathrm{K}=\mathrm{K}_{\mathrm{e}}+\mathrm{K}_{\mathrm{n}}
$$

Thus, carbon emission function might be specified as:

$$
\mathrm{CO}_{2}(\mathrm{t})=\phi \mathrm{K}_{\mathrm{e}}(\mathrm{Y})
$$

As in Equation (1), Y is a function of GDP, so it can be written as follows:

$$
\ln \mathrm{CO}_{2}(\mathrm{t})=\beta_{0}+\beta_{1} \mathrm{CO}_{2 \mathrm{t}}+\beta_{2} \mathrm{GDP}_{\mathrm{t}}+\varepsilon_{\mathrm{t}}
$$

Furthermore, the concentration of carbon emission increases as a consequence of forest cover change, deforestation and forest degradation. Therefore, forested area (FA) can be taken as a proxy of core factors to explain the impacts of carbon emission dynamics. Hence, the model might be specified as:

$$
\ln \mathrm{CO}_{2}(\mathrm{t})=\beta_{0}+\beta_{1} \mathrm{CO}_{2 \mathrm{t}}+\beta_{2} \mathrm{GDP}_{\mathrm{t}}+\beta_{3} \mathrm{FA}_{\mathrm{t}}+\varepsilon_{\mathrm{t}}
$$

According to Grossman and Krueger [8], the non-linear relationship between GDP and carbon emission which can be considered by the following model:

$$
\ln \mathrm{CO}_{2}(\mathrm{t})=\beta_{0}+\beta_{1} \mathrm{LCO}_{2 \mathrm{t}}+\beta_{2} \mathrm{LGDP}_{\mathrm{t}}+\beta_{3} \mathrm{LFA}_{\mathrm{t}}+\varepsilon_{\mathrm{t}}
$$


However, the key advantage of the DOLS estimation reflects the existence of mixed order integration of individual variables in the cointegrated outline. For instance, DOLS estimation involved regressing one of $\mathrm{I}(1)$ variables compared to other variables, some of which are $\mathrm{I}(1)$ with leads $(\mathrm{p})$ and lags $(-p)$ of the first difference whereas others are $\mathrm{I}(0)$ variables that include a constant term [48]. Accordingly, this estimation provides the solutions of small sample bias, endogeneity and auto correlation problems due to accumulating the leads and lags among explanatory variable [49]. Finally, this study estimates the following equation:

$$
\begin{aligned}
\Delta \ln \mathrm{CO}_{2}=\beta_{0}+ & \beta_{1} \ln \mathrm{CO}_{2 \mathrm{t}-1}+\beta_{2} \mathrm{LGDP}_{\mathrm{t}-1}+\beta_{3} \mathrm{LFA}_{\mathrm{t}-1}+\sum_{\mathrm{i}=1}^{\mathrm{p}} \gamma_{\mathrm{i}} \ln \mathrm{CO}_{2 \mathrm{t}-\mathrm{i}} \\
& +\sum_{\mathrm{j}=1}^{\mathrm{q}} \delta_{\mathrm{j}} \Delta \mathrm{GDP}_{\mathrm{t}-\mathrm{j}}+\sum_{\mathrm{k}=1}^{\mathrm{q}} \varphi_{\mathrm{k}} \Delta \mathrm{FA} A_{\mathrm{t}-\mathrm{k}}+\varepsilon_{\mathrm{t}}
\end{aligned}
$$

where $\mathrm{CO}_{2 \mathrm{t}}$ is the annual $\mathrm{CO}_{2}$ emission in kt; FAt is the annual forested area in hectare; and GDPt is the annual GDP in million RM. The coefficients ( $\beta 1, \beta 2$ and $\beta 3)$ denote the long-run elasticities of the explanatory variables such as carbon emissions, GDP and forested area, respectively.

\section{Results}

Table 2 provides simple descriptive statistics of variables such as mean, standard error, median, standard deviation, minimum and maximum values both in actual and logarithmic form of the variables. Each variable included 27 observations of time series data from 1990 to 2016 for Malaysia. Moreover, skewness and kurtosis values reveal that the variables are normally distributed. These statistics lead us to proceed the unit root test for stationarity of the variables as well as further analysis of the DOLS estimation.

Table 2. Descriptive statistics of variables.

\begin{tabular}{ccccccc}
\hline & \multicolumn{2}{c}{$\begin{array}{c}\mathbf{C O}_{2} \text { Emissions } \\
\text { (Kilo Yons) }\end{array}$} & \multicolumn{2}{c}{ GDP (Million RM) } & \multicolumn{2}{c}{ Forest Area (ha) } \\
\cline { 2 - 7 } Variables & Actual & $\begin{array}{c}\text { Logarithmic } \\
\text { (LCO } \mathbf{2})\end{array}$ & Actual & $\begin{array}{c}\text { Logarithmic } \\
\text { (LGDP) }\end{array}$ & Actual & $\begin{array}{c}\text { Logarithmic } \\
\text { (LFA) }\end{array}$ \\
\cline { 2 - 7 } & & 11.8930 & $699,714.75$ & 13.381 & $18,145,570.1$ & 16.7138 \\
Mean & $157,853.74$ & 0.0799 & $52,409.542$ & 0.0789 & $60,104.182$ & 0.0033 \\
Etandard & $11,313.046$ & 11.972 & $648,959.53$ & 13.3831 & $18,056,000$ & 16.709 \\
Median & $158,256.71$ & 0.4151 & $272,327.97$ & 0.4099 & $312,310.49$ & 0.0172 \\
Standard & $58,784.31$ & -0.4021 & -0.8810 & -0.83865 & -0.7572 & -0.7803 \\
Deviation & -1.1566 & -0.5811 & 0.3664 & -0.253 & 0.4209 & 0.394 \\
Kurtosis & 0.0551 & 10.9436 & $291,457.46$ & 12.5826 & $17,681,000$ & 16.688 \\
Skewness & $56,592.81$ & 12.4405 & $1,229,312$ & 14.022 & $18,782,000$ & 16.7484 \\
Minimum & $252,838.58$ & & & & & \\
Maximum & & &
\end{tabular}

We proceeded to do the unit root test to justify the suitability of employing DOLS estimation instead of cointegration approach by confirming no variable exceeded the order of integration I(1). Thus, we applied the augmented Dickey-Fuller (ADF) and Dickey-Fuller generalised least squares (DF-GLS) approaches based on the trends and constants to detect the autoregressive unit root $[50,51]$. Table 3 summarises the findings of unit root tests by ADF and DF-GLS. The ADF test result indicates that $\mathrm{LCO}_{2}$ found stationary at the level and remained stationary after taking first difference while both LGDP and LFA were found non-stationary at the level but become stationary at the first difference. On the other hand, the DF-GLS test illustrated all variables with non-stationary at the level and become stationary after first difference. Hence, the existence of mixed orders integration for variables estimated by the ADF and DF-GLS also validates use of the DOLS analysis. 
Table 3. Findings of unit root tests by augmented Dickey-Fuller (ADF) and Dickey-Fuller generalised least squares (DF-GLS).

\begin{tabular}{ccccc}
\hline \multirow{2}{*}{ Logarithmic Form of the Variables } & \multicolumn{2}{c}{ ADF } & \multicolumn{2}{c}{ DF-GLS } \\
\cline { 2 - 5 } & Level & 1st Difference & Level & 1st Difference \\
\hline $\mathrm{CO}_{2}$ emissions $\left(\mathrm{LCO}_{2}\right)$ & $-2.588^{*}$ & $-3.062^{* *}$ & -2.068 & $-3.181^{*}$ \\
Economic growth (LGDP) & -1.922 & $-3.699^{* * *}$ & -1.505 & $-4.024^{* * *}$ \\
Forested area (LFA) & -2.151 & $-2.752^{*}$ & -0.515 & $-3.300^{*}$ \\
\hline
\end{tabular}

$* * * * *$, and $*$ denote significance at the $1 \%, 5 \%$, and $10 \%$ levels, respectively.

Moreover, Granger causality tests used to identify the causalities between the variables. Table 4 presents the results from Granger causality Wald tests indicating bidirectional causality existence between $\mathrm{CO}_{2}$ emission to economic growth, $\mathrm{CO}_{2}$ emission to forested area and economic growth to forested area. This result also justified for using lagged variables in the DOLS estimation.

Table 4. Results of Granger causality Wald tests.

\begin{tabular}{ccccc}
\hline \multicolumn{2}{c}{ Equation/Excluded } & Chi-Square & Df. & $p$-Value \\
\hline \multirow{2}{*}{$\mathrm{LCO}_{2}$} & LGDP & $26.129^{* * *}$ & 4 & 0.000 \\
& LFA & $41.907^{* * *}$ & 4 & 0.000 \\
& All & $89.686^{* * *}$ & 8 & 0.000 \\
\hline \multirow{3}{*}{ LGDP } & $\mathrm{LCO}_{2}$ & $12.953^{* * *}$ & 4 & 0.012 \\
& LFA & $22.979^{* * *}$ & 4 & 0.000 \\
& All & $33.688^{* * *}$ & 8 & 0.000 \\
\hline \multirow{2}{*}{ LFA } & LCO & $21.872^{* * *}$ & 4 & 0.000 \\
& LGDP & $23.347^{* * *}$ & 4 & 0.000 \\
& All & $30.669^{* * *}$ & 8 & 0.000 \\
\hline \multicolumn{4}{c}{$* * *$ and $^{* *}$ denote significant level of $1 \%$ and $5 \%$, respectively. }
\end{tabular}

Table 5 presents the results of DOLS estimated by Equation (8). The coefficient value of GDP shows a positive relationship with $\mathrm{CO}_{2}$ emissions that is statistically significant at $1 \%$ level. This means that a RM1 million rise in GDP is associated to an increase in $\mathrm{CO}_{2}$ emissions of $0.931 \mathrm{kt}$, all other things constant. Instead, the results showed a negative coefficient of forested area on $\mathrm{CO}_{2}$ emissions with $1 \%$ level of significance. This implies that declining one hectare of forested area (i.e., deforestation) has an impact of three kilo tons of $\mathrm{CO}_{2}$ emissions rise in Malaysia. It is noteworthy that the signs of the estimated coefficients are consistent both from theoretical point of view and practical expectations. In addition, we investigated our estimated model's goodness of fit with some diagnostic tests. First, the value of $R^{2}$ and adjusted $R^{2}$ were 0.9838 and 0.9825 , respectively, depicting a very good fitting of the estimated regression model. This clarifies $98 \%$ of the variation in change of dependent variable can be explained by the independent variables. Second, the F-test indicated that the estimated DOLS regression is justified by its dependent and independent variable. The $p$ value of F-test was less than 0.0001, meaning that the linear relation of the model was statistically significant. Third, the root mean square error (RMSE) provided an accurate measure of model predictions for various times. The value of RMSE was 0.055 (close to 0 ) and non-negative, indicating the results of DOLS model was an almost perfect fit to the data.

Our findings prove that economic growth has a significant impact on $\mathrm{CO}_{2}$ emissions, where GDP growth fosters $\mathrm{CO}_{2}$ emissions at a faster rate in Malaysia. In line with this, Holtz-Eakin and Selden [52]; and Shafik [53] found a monotonic relationship between $\mathrm{CO}_{2}$ emissions and income levels. Our findings are also supported by other studies in Malaysia such as Azlina and Mustapha [54], who reported Granger causality relations among economic growth, energy consumption and pollutant emissions. Ang [25] also found a bidirectional relation from economic growth to energy consumption in Malaysia. The present study found strong causality from $\mathrm{CO}_{2}$ emission to deforestation, from economic growth 
to $\mathrm{CO}_{2}$ emission, and from deforestation to $\mathrm{CO}_{2}$ emission. Nevertheless, compromising between economic growth and forest conservation is a central issue of sustainability in terms of $\mathrm{CO}_{2}$ emissions; that is why this article did not consider other factors such as energy consumption, population, poverty and so on. Moreover, our study is distinct from those previous, as it is based on the latest and greater data set of 1990 to 2016. In addition, Bilan et al. [55] found long-run causality from $\mathrm{CO}_{2}$ emissions to GDP for EU countries whereas Pao et al. [56] found bidirectional long-run Granger causality of $\mathrm{CO}_{2}$ emissions and economic growth in Brazil, Russia, India, and China (BRIC) countries. Wang et al. [57] reported that in the long run, energy consumption and economic growth have positive impacts for $\mathrm{CO}_{2}$ emissions in China. According to Tiwari [58], $\mathrm{CO}_{2}$ emissions Granger-causes GDP while, GDP does not Granger-cause $\mathrm{CO}_{2}$ emissions in India. Instead, Ozturk and Acaravci [59] found no causal evidence from the per capita real GDP to per capita carbon emissions in Turkey.

Table 5. Results of DOLS; dependent variable, $\mathrm{LCO}_{2}$.

\begin{tabular}{ccccc}
\hline Variables & Coefficient & Standard Error & t-Statistic & $p$-Value \\
\hline GDP (LGDP) & $0.9313719^{* * *}$ & 0.0313171 & 29.74 & 0.000 \\
Forested area (LFA) & $-2.972577^{* * *}$ & 0.7481949 & -3.97 & 0.001 \\
Constant & $49.11344^{* * *}$ & 12.73751 & 3.86 & 0.001 \\
\hline Number of observations & 27 & & & \\
df (degrees of freedom) & 26 & & \\
R-squared & 0.9838 & & \\
Adjusted R-squared & 0.9825 & & \\
Standard error of the estimate & 13.51702 & & \\
Mean of dependent variable & 11.89308 & & \\
F-value & 9.3393529 & & \\
Prob $>$ F & 0.0000 & & \\
Root MSE & 0.05497 & & \\
& $* * *$ denote significance at the 1\% level.
\end{tabular}

Moreover, some studies revealed the environmental Kuznets curve (EKC) presenting the simple trail of economic growth and environmental pollutions or emissions for various countries including EU [55,60,61], Organisation of Islamic Cooperation (OIC) countries [32], and BRIC [56]; Middle East and North Africa (MENA) [62]; Organisation for Economic Co-operation and Development (OECD) [63]; industrialised [64]; and small-economy countries [65]. Furthermore, some studies are based on single country such as Bangladesh [15]; China [57,66-71]; Turkey [59]; South Korea [72]; India [58]; and the USA $[23,73]$. It is noteworthy that none of these studies have taken into consideration deforestation as an independent variable. However, our study findings indicate the long run relationship and impacts of the forested/deforested area and economic growth on $\mathrm{CO}_{2}$ emissions in Malaysia. Our findings are also supported by other studies, although they used different set of variables and methods of analysis. For instance, Mansson et al. [74] combined DOLS with the Ridge regression estimator in order to demonstrate the EKC for a wide variety of different situations in energy economics and environmental studies. Islam et al. [75] reported a negative relationship of forested area with the $\mathrm{CO}_{2}$ emission along with other socioeconomic variables by using cointegration and vector error-correction modelling techniques. Nepal et al. [76] analysed the relationship between global forested area and economic growth under the EKC framework. Nevertheless, any program and activities that escalate forests would be valuable for controlling and managing Malaysia's rising GHG emissions. The novelty of this study offers new findings with the latest estimation of the dynamic impacts of economic growth and forested area on carbon dioxide emissions by using 27 years of time series data in Malaysia. The findings indicate the importance of Malaysia's green growth and urgent action to combat climate change impacts associated with the forestry sector. 


\section{Discussion and Implications for Sustainability}

Our findings from DOLS regression showed that an increase in GDP and deforestation (declining forested area) leads to an increase in $\mathrm{CO}_{2}$ emissions in Malaysia. Malaysia is a tropical country with $67.55 \%$ of forested area [40] that plays various beneficial roles for environmental protection and sustainability including emission reduction through atmospheric carbon sequestration and reducing climate change [44]. GHG emission through the forestry sector are mainly associated with cutting down the trees. Reduction of GHG emissions from the forestry sector can be possible by reducing timber harvesting as well as minimizing deforestation and forest degradation [46]. Hence, deforestation is a major concern for sustainable management of environment and natural resources because it affects the climatic system so badly. However, the rate of deforestation is still high in Malaysia. Thus, it is a matter of concern that restoring forested area, high economic growth and better environmental quality through emissions reduction are jointly exclusive.

However, the atmospheric accumulation of $\mathrm{CO}_{2}$ and its possible greenhouse effect on global climatic system has become a major environmental issue [77]. Forests keep a crucial role in regulating climate change by controlling the quantity of atmospheric $\mathrm{CO}_{2}$. Forests perform as both sources and sinks of GHG, through which they have a vital impact on the global climatic system [78]. For the past few decades, tropical countries have been experiencing rapid land use and forest cover changes due to heavy deforestation [79]. Deforestation in the tropical region is the second major source of GHG emissions, responsible for almost five billion tons $\mathrm{CO}_{2}$ emissions per year, which is about $17 \%$ of the total worldwide emissions of $\mathrm{CO}_{2}$ to atmosphere, causing global warming and climate change [80]. Clearing forests by cutting down the trees is the most significant cause of deforestation all over the world. For instance, huge tropical forests have been converted to agriculture because of increasing population and their economic opportunities [81]. However, Malaysia is one of the Southeast Asian countries which is rich in biodiversity [82]. Malaysia has experienced biodiversity loss and the destruction of wildlife habitat because of the forest cover changes over the last few decades due to heavy deforestation. Uncontrolled development and land use changes are threatening these forests, causing both deforestation and degradation of the natural forested areas. At the beginning of the 20th century, forests covered almost $90 \%$ of the total area of Peninsular Malaysia [30]. In comparison, only 44\% of Peninsular Malaysia consisted of forested areas in 2016 [28]. These remaining forests are also frequently fragmented, leading to loss of habitat for many important species.

Furthermore, avoiding deforestation makes great sense from a functional viewpoint. Conserving forests in tropical regions may hold 300-400 tons $\mathrm{CO}_{2}$ per hectare in forest biomass [83]. However, it is not possible to diminish the global climate change problem without reducing the emissions from deforestation. There are a few countries that have proposed a mechanism to pay developing countries with a higher deforestation rate for conserving their forest areas and reducing deforestation and degradation. The Malaysian government is also implementing different policy instruments; for example, REDD+ (Reducing Emissions from Deforestation and forest Degradation), which includes the role of conservation, sustainable management of forests and enhancement of forest carbon stocks $[79,84,85]$. Thus, $\mathrm{CO}_{2}$ emissions can be minimised by applying these programs. Appropriate implementation of these forestry instruments can decrease the deforestation rate by managing and controlling the forest logging activities, which ultimately provide support for the worldwide effort to reduce GHG emissions as well as to increase national economic growth. Malaysia has given its attention to the beneficial role played by forestry sector; for example, watershed conservation, soil protection, biodiversity conservation, fulfilling aesthetic and recreational demands from the tourists, climatic system regulation and carbon sinks. These beneficial roles by the forestry sector can take part to reduce climate change vulnerabilities and to mitigate climate change. Therefore, Malaysia planned to maintain a minimum $50 \%$ of its total land as forested areas [44]. Malaysia is one of the signatory countries of the Kyoto Protocol and has ratified to reduce GHG emissions [37].

Moreover, Malaysia has undertaken several efforts to address climate change actions including adaptation and mitigation, and continually reevaluates its mitigation potential in various key sectors. 
These actions have contributed to achieve Malaysia's conditional voluntary indicator to reduce its GHG emissions intensity of GDP by $45 \%$ by 2030 relative to the emissions intensity of GDP in 2005, consisting of $35 \%$ on an unconditional basis and a further $10 \%$ on a condition upon receipt of climate finance, technology transfer and capacity building from developed countries [44]. The Malaysian forestry sector has attracted some interest from the international community to address emissions reduction [43]. Nevertheless, appropriate implementation of emission reduction policies with sufficient investment for emission reduction through the forestry sector could be a possible way for Malaysia to achieve the goals for sustainable environment and long run economic growth [33]. Government initiatives for increasing forest carbon biomass with implementing policies related to carbon trading scheme and carbon emissions tax can be supportive for Malaysia's long-term economic growth. The potential impact of forest carbon sequestration through various forestry related mitigation activities such as afforestation, reforestation, forest conservation, and sustainable forest management, etc., and their cost-effectiveness could play a significant role in environmental sustainability by reducing global GHG emissions with low cost compared to other non-forestry GHG emission reduction technologies. Instead, plantation activities can be carried out in appropriate areas such as vacant land and bare hills to limit and prevent the destruction of existing natural forests. Therefore, $\mathrm{CO}_{2}$ emission reduction through the forestry sector of Malaysia could reduce the financial barriers to mitigate climate change while accelerating the national economy.

\section{Conclusions}

The results of DOLS estimation reveal that economic growth and deforested areas have an adverse impact on Malaysia's carbon emissions where GDP growth fosters carbon emissions at a faster rate. The vital advantage of the DOLS approach is that it also reflects the existence of a mix order integration of variables as like co-integrated approach. The estimated DOLS encompasses regressing one of the I(1) variables against other I(1) and I(0) variables [25], hence, the plausible endogenous and small sample bias problems can be solved. Thus, the obtained estimation of our DOLS model are asymptotically efficient. The overall findings imply that forest protection and conservation is crucial to reduce carbon emissions. Thus, the effective implementation of national climate change, green technology and environmental policies together with economic instruments in the forestry sector including REDD+ mechanism, afforestation and reforestation (tree planting programs), forest conservation and sustainable forest management, among others, could be useful for reducing carbon emissions while decreasing deforestation and maintaining long-term economic growth in Malaysia. Nevertheless, the significant contribution of this study is to investigate the inter-temporal links in the forested area/deforestation-environment-economic nexus for Malaysia that could be helpful for policy makers to understand their relationships for design and implementing effective forest management as well as climate change and environmental policies. The facts, trends and empirical evidence of dynamic impacts and relationship of economic growth, forested area and carbon emissions might help to frame issues and challenges of current forest management practices that affect the response to lowering carbon emissions, tackling climate change and improving environmental quality and sustainability in Malaysia. Finally, this article can serve as an entry point for comprehensive researches of climate change mitigation strategies in order to implement effective policy measures for achieving sustainable forest management and a low carbon economy in Malaysia.

Author Contributions: Conceptualisation, R.A.B.; methodology and formal analysis, R.A.B. and A.R.; data curation and software, A.R.; validation, R.A.B.; writing-original draft preparation, A.R. and R.A.B.; writing-review and editing, R.A.B., A.R. and M.N.M.S.; supervision, R.A.B. and M.N.M.S.; project administration, R.A.B.; funding acquisition, R.A.B. All authors have read and agreed to the published version of the manuscript.

Funding: This research was supported by 'Trans Disciplinary Research Grant Scheme (TRGS)' under the Ministry of Education, Malaysia (TRGS/1/2015/UKM/02/5/3) and UKM-Yayasan Sime Darby Chair TKE14.

Conflicts of Interest: The authors declare no conflict of interest. 


\section{References}

1. IPCC. Contribution to the Intergovernmental Panel on Climate Change, Fifth Assessment Report Climate Change WG I, 2013: The Physical Science Basis Summary for Policymakers; IPCC Working Group I: Stockholm, Sweden, 2013.

2. FAO. Global Forest Resources Assessment; Food and Agricultural Organization of United Nations: Rome, Italy, 2015.

3. Hansen, M.C.; Potapov, P.V.; Moore, R.; Hancher, M.; Turubanova, S.; Tyukavina, A.; Thau, D.; Stehman, S.V.; Goetz, S.J.; Loveland, T.R.; et al. High-resolution global maps of 21st-century forest cover change. Science 2013, 342, 850-853. [CrossRef] [PubMed]

4. Houghton, R.A. Carbon emissions and the drivers of deforestation and forest degradation in the tropics. Curr. Opin. Environ. Sustain. 2012, 4, 597-603. [CrossRef]

5. Lewis, S.L. Tropical forests and the changing earth system. Philos. Trans. R. Soc. Lond. B Biol. Sci. 2006, 361, 195-210. [CrossRef]

6. Malhi, Y.; Grace, J. Tropical forests and atmospheric carbon dioxide. Trends Ecol. 2000, 15, 332-337. [CrossRef]

7. Jaafar, W.S.W.M.; Maulud, K.N.A.; Kamarulzaman, A.M.M.; Raihan, A.; Sah, S.M.; Ahmad, A.; Saad, S.N.M.; Azmi, A.T.M.; Syukri, N.K.A.J.; Khan, W.R. The Influence of Deforestation on Land Surface Temperature-A Case Study of Perak and Kedah, Malaysia. Forests 2020, 11, 670. [CrossRef]

8. Shafik, N.; Bandyopadhyay, S. Economic Growth and Environmental Quality: Time Series and Cross-Country Evidence; WPS 904; The World Bank: Washington, DC, USA, 1992.

9. Parajuli, R.; Joshi, O.; Maraseni, T. Incorporating forests, agriculture, and energy consumption in the framework of the Environmental Kuznets Curve: A dynamic panel data approach. Sustainability 2019, 11, 2688. [CrossRef]

10. Van derWerf, G.R.; Morton, D.C.; DeFries, R.S.; Olivier, J.G.J.; Kasibhatla, P.S.; Jackson, R.B.; Collatz, G.J.; Randerson, J.T. $\mathrm{CO}_{2}$ emissions from forest loss. Nat. Geosci. 2009, 2, 737-738. [CrossRef]

11. Begum, R.A.; Sohag, K.; Abdullah, S.M.S.; Jaafar, M. $\mathrm{CO}_{2}$ emissions, energy consumption, economic and population growth in Malaysia. Renew. Sustain. Energy Rev. 2015, 41, 594-601. [CrossRef]

12. Grossman, G.M.; Krueger, A.B. Economic growth and the environment. Q. J. Econ. 1995, 110, 353-377. [CrossRef]

13. Li, D.; Yang, D. Does Non-Fossil Energy Usage Lower $\mathrm{CO}_{2}$ Emissions? Empirical Evidence from China. Sustainability 2016, 8, 874. [CrossRef]

14. Mitić, P.; Munitlak Ivanović, O.; Zdravković, A. A cointegration analysis of real GDP and $\mathrm{CO}_{2}$ emissions in transitional countries. Sustainability 2017, 9, 568. [CrossRef]

15. Narayan, P.K.; Narayan, S. Carbon dioxide emissions and economic growth: Panel data evidence from developing countries. Energy Policy 2010, 38, 661-666. [CrossRef]

16. Park, J.; Hong, T. Analysis of South Korea's economic growth, carbon dioxide emission, and energy consumption using the Markov switching model. Renew. Sustain. Energy Rev. 2013, 18, 543-551. [CrossRef]

17. Hussain, M.; Javid, M.I.; Drake, P.R. An econometric study of carbon dioxide $\left(\mathrm{CO}_{2}\right)$ emissions, energy consumption, and economic growth of Pakistan. Int. J. Energy Sect. Manag. 2012, 6, 518-533. [CrossRef]

18. Alam, M.J.; Begum, I.A.; Buysse, J.; Huylenbroeck, G.V. Energy consumption, carbon emissions and economic growth nexus in Bangladesh: Cointegration and dynamic causality analysis. Energy Policy 2012, 45, $217-225$. [CrossRef]

19. Wang, K.M. Modelling the nonlinear relationship between $\mathrm{CO}_{2}$ emissions from oil and economic growth. Econ. Model. 2012, 29, 1537-1547. [CrossRef]

20. Fei, L.; Dong, S.; Xue, L.; Liang, Q.; Yang, W. Energy consumption-economic growth relationship and carbon dioxide emissions in China. Energy Policy 2011, 39, 568-574. [CrossRef]

21. Chang, C.C. A multivariate causality test of carbon dioxide emissions, energy consumption and economic growth. Appl. Energy 2010, 87, 3533-3537. [CrossRef]

22. Pao, H.T.; Tsai, C.M. $\mathrm{CO}_{2}$ emissions, energy consumption and economic growth in BRIC countries. Energy Policy 2010, 38, 7850-7860. [CrossRef]

23. Menyah, K.; Wolde-Rufael, Y. Energy consumption, pollutant emissions and economic growth in South Africa. Energy Econ. 2010, 32, 1374-1382. [CrossRef]

24. Soytas, U.; Sari, R. Energy consumption, economic growth, and carbon emissions: Challenges faced by an EU candidate member. Ecol. Econ. 2009, 68, 1667-1675. [CrossRef] 
25. Ang, J.B. Economic development, pollutant emissions and energy consumption in Malaysia. J. Policy Model. 2008, 30, 271-278. [CrossRef]

26. Paluš, H.; Parobek, J.; Moravčík, M.; Kovalčík, M.; Dzian, M.; Murgaš, V. Projecting Climate Change Potential of Harvested Wood Products under Different Scenarios of Wood Production and Utilization: Study of Slovakia. Sustainability 2020, 12, 2510. [CrossRef]

27. Nabuurs, G.; Delacote, P.; Ellison, D.; Hanewinkel, M.; Lindner, M.; Nesbit, M.; Ollikainen, M.; Savaresi, A. A New Role for Forests and the Forest Sector in the EU Post-2020 Climate Targets; From Science to Policy 2; European Forest Institute: Joensuu, Finland, 2015; ISBN 9789525980219.

28. MNRE. Total Forested Areas in Malaysia (1990-2014). Official Portal Ministry of Natural Resources and Environment (MNRE), Malaysia. Available online: http://www.nre.gov.my/en-my/Forestry/Pages/StatisticsForest.aspx (accessed on 29 January 2020).

29. Terrier, A.; Paquette, M.; Gauthier, S.; Girardin, M.P.; Pelletier-Bergeron, S.; Bergeron, Y. Influence of fuel load dynamics on carbon emission by wildfires in the Clay Belt boreal landscape. Forests 2017, 8, 9. [CrossRef]

30. Jomo, K.S.; Chang, Y.T.; Khoo, K.J. Deforesting Malaysia: The Political Economy and Social Ecology of Agricultural Expansion and Commercial Logging; Zed Books Ltd.: London, UK, 2004.

31. Osman, R.; Phua, M.H.; Ling, Z.Y.; Kamlun, K.U. Monitoring of Deforestation Rate and Trend in Sabah between 1990 and 2008 Using Multi temporal Landsat Data. J. For. Sci. 2012, 28, 144-151.

32. Shaari, M.S.; Abdul Karim, Z.; Zainol Abidin, N. The Effects of Energy Consumption and National Output on $\mathrm{CO}_{2}$ Emissions: New Evidence from OIC Countries Using a Panel ARDL Analysis. Sustainability 2020, 12, 3312. [CrossRef]

33. Roda, J.M.; Kamaruddin, N.; Tobias, R.P. Deciphering corporate governance and environmental commitments among southeast Asian transnationals: Uptake of sustainability certification. Forests 2015, 6, 1454-1475. [CrossRef]

34. Saboori, B.; Sulaiman, J.; Mohd, S. Economic growth and $\mathrm{CO}_{2}$ emissions in Malaysia: A cointegration analysis of the environmental Kuznets curve. Energy Policy 2012, 51, 184-191. [CrossRef]

35. Noraida, A.W.; Abdul-Rahim, A.S.; Mohd-Shahwahid, H.O. The Impact of Sustainable Forest Management (SFM) Practices On Primary Timber-Based Production in Peninsular Malaysia. JEM 2017, 51, 159-177.

36. Jaafar, A.H.; Salleh, N.H.M.; Manaf, Z.A. Intersectoral linkages in oil palm industry between Malaysia and Indonesia. JEM 2015, 49, 25-35. [CrossRef]

37. ShriDewi, A.; Ali, A.M.; Alias, M.H. Impact of biodiesel blend mandate (B10) on the Malaysian palm oil industry. JEM 2014, 48, 29-40.

38. Alias, M.H.; Arshad, F.M.; Rahman, A.A.A. Market share analysis of Malaysia's palm oil exports: Implications on its competitiveness. JEM 1992, 26, 3-20.

39. Ismail, R. An economic evaluation of carbon emission and carbon sequestration for the forestry sector in Malaysia. Biomass Bioenergy 1995, 8, 281-292. [CrossRef]

40. World Bank. World Development Indicators (WDI); Data series by The World Bank Group; The World Bank: Washington, DC, USA, 2015.

41. Ismail, R. Long-term growth in Malaysia: An application of endogenous neoclassical growth model. JEM 1999, 33, 105-121.

42. CCPI. Climate Change Performance Index Report 2020; German Watch, the European Union and the Barthel Foundation: Bonn, Germany; Brussels, Belgium, 2020.

43. MNRE. Malaysia's First Biennial Update Report (BUR) Submitted to the United Nations Framework Convention on Climate Change (UNFCCC) in December 2015; Ministry of Natural Resources and Environment (MNRE): Putrajaya, Malaysia, 2015.

44. MNRE. Second National Communication (NC2) to the UNFCCC 2011; Official Portal Ministry of Natural Resources and Environment (MNRE): Putrajaya, Malaysia, 2011.

45. Rashid, Z.A.; Rahman, A.A.A.; Othman, M.S.; Suib, A. Tourism impact analysis-An inter-sectoral analysis of the Malaysian economy. JEM 1993, 27, 99-119.

46. Pesaran, M.H.; Shin, Y. An autoregressive distributed lag modeling approach to cointegration analysis. In Econometrics and Economic Theory in 20th Century: The Ragnar Frisch Centennial Symposium; Strom, S., Ed.; Cambridge University Press: Cambridge, UK, 1999; p. 11.

47. Pesaran, M.H.; Shin, Y.; Smith, R.J. Bounds testing approaches to the analysis of level relationships. J. Appl. Econ. 2001, 16, 289-326. [CrossRef] 
48. Alcántara, V.; Padilla, E. Input-output subsystems and pollution: An application to the service sector and $\mathrm{CO}_{2}$ emissions in Spain. Ecol. Econ. 2009, 68, 905-914. [CrossRef]

49. Stock, J.H.; Watson, M.W. A simple estimator of cointegrating vectors in higher order integrated systems. Econometrica 1993, 61, 783-820. [CrossRef]

50. Dickey, D.; Fuller, W. Likelihood Ratio Statistics for Autoregressive Time Series with a Unit Root. Econometrica 1981, 49, 1057-1071. [CrossRef]

51. Elliot, G.; Rothenberg, T.J.; Stock, J.H. Efficient tests for an autoregressive unit root. Econometrica 1996, 64, 813-836. [CrossRef]

52. Holtz-Eakin, D.; Selden, T.M. Stoking the fires? $\mathrm{CO}_{2}$ emissions and economic growth. J. Public Econ. 1995, 57, 85-101. [CrossRef]

53. Shafik, N. Economic development and environmental quality: An econometric analysis. Oxf. Econ. Pap. 1994, 46, 75-773. [CrossRef]

54. Azlina, A.A.; Mustapha, N.H. Energy, economic growth and pollutant emissions nexus: The case of Malaysia. Procedia-Soc. Behav. Sci. 2012, 65, 1-7. [CrossRef]

55. Bilan, Y.; Streimikiene, D.; Vasylieva, T.; Lyulyov, O.; Pimonenko, T.; Pavlyk, A. Linking between renewable energy, $\mathrm{CO}_{2}$ emissions, and economic growth: Challenges for candidates and potential candidates for the EU membership. Sustainability 2019, 11, 1528. [CrossRef]

56. Pao, H.T.; Tsai, C.M. Multivariate Granger causality between $\mathrm{CO}_{2}$ emissions, energy consumption, FDI (foreign direct investment) and GDP (gross domestic product): Evidence from a panel of BRIC (Brazil, Russian Federation, India, and China) countries. Energy 2011, 36, 685-693. [CrossRef]

57. Wang, S.S.; Zhou, D.Q.; Zhou, P.; Wang, Q.W. $\mathrm{CO}_{2}$ emissions, energy consumption and economic growth in China: A panel data analysis. Energy Policy 2011, 39, 4870-4875. [CrossRef]

58. Tiwari, A.K. Energy consumption, $\mathrm{CO}_{2}$ emissions and economic growth: Evidence from India. JIBE 2011, 12, 85-122. [CrossRef]

59. Ozturk, I.; Acaravci, A. $\mathrm{CO}_{2}$ emissions, energy consumption and economic growth in Turkey. Renew. Sustain. Energy Rev. 2010, 14, 3220-3225. [CrossRef]

60. Neagu, O.; Teodoru, M.C. The relationship between economic complexity, energy consumption structure and greenhouse gas emission: Heterogeneous panel evidence from the EU countries. Sustainability 2019, 11, 497. [CrossRef]

61. Neagu, O. The Link between Economic Complexity and Carbon Emissions in the European Union Countries: A Model Based on the Environmental Kuznets Curve (EKC) Approach. Sustainability 2019, 11, 4753. [CrossRef]

62. Arouri, M.E.H.; Youssef, A.B.; M'henni, H.; Rault, C. Energy consumption, economic growth and $\mathrm{CO}_{2}$ emissions in Middle East and North African countries. Energy Policy 2012, 45, 342-349. [CrossRef]

63. Saboori, B.; Sapri, M.; Baba, M. Economic growth, energy consumption and $\mathrm{CO}_{2}$ emissions in OECD (Organization for Economic Co-operation and Development)'s transport sector: A fully modified bi-directional relationship approach. Energy 2014, 66, 150-161. [CrossRef]

64. Hossain, M.S. Panel estimation for $\mathrm{CO}_{2}$ emissions, energy consumption, economic growth, trade openness and urbanization of newly industrialized countries. Energy Policy 2011, 39, 6991-6999. [CrossRef]

65. Friedl, B.; Getzner, M. Determinants of $\mathrm{CO}_{2}$ emissions in a small open economy. Ecol. Econ. 2003, 45, $133-148$. [CrossRef]

66. Sun, J.; Shi, J.; Shen, B.; Li, S.; Wang, Y. Nexus among energy consumption, economic growth, urbanization and carbon emissions: Heterogeneous panel evidence considering China's regional differences. Sustainability 2018, 10, 2383. [CrossRef]

67. Weber, C.L.; Peters, G.P.; Guan, D.; Hubacek, K. The contribution of Chinese exports to climate change. Energy Policy 2008, 36, 3572-3577. [CrossRef]

68. Yunfeng, Y.; Laike, Y. China's foreign trade and climate change: A case study of $\mathrm{CO}_{2}$ emissions. Energy Policy 2010, 38, 350-356. [CrossRef]

69. Bloch, H.; Rafiq, S.; Salim, R. Coal consumption, $\mathrm{CO}_{2}$ emission and economic growth in China: Empirical evidence and policy responses. Energy Econ. 2012, 34, 518-528. [CrossRef]

70. Choi, Y.; Zhang, N.; Zhou, P. Efficiency and abatement costs of energy-related $\mathrm{CO}_{2}$ emissions in China: A slacks-based efficiency measure. Appl. Energy 2012, 98, 198-208. [CrossRef] 
71. Hang, G.; Yuan-Sheng, J. The relationship between $\mathrm{CO}_{2}$ emissions, economic scale, technology, income and population in China. Procedia Environ. Sci. 2011, 11, 1183-1188. [CrossRef]

72. Baek, J.; Kim, H.S. Is economic growth good or bad for the environment? Empirical evidence from Korea. Energy Econ. 2013, 36, 744-749. [CrossRef]

73. Soytas, M.A.; Denizel, M.; Usar, D. Corporate Sustainability: Empirical Evidence of Causality on Financial Performance; Working Paper; Iowa State University: Ames, IA, USA, 2017. [CrossRef]

74. Månsson, K.; Kibria, B.M.; Shukur, G.; Sjölander, P. On the estimation of the $\mathrm{CO}_{2}$ emission, economic growth and energy consumption nexus using dynamic OLS in the presence of multicollinearity. Sustainability 2018, 10, 1315. [CrossRef]

75. Islam, R.; Ghani, A.B.A.; Mahyudin, E. Carbon Dioxide Emission, Energy Consumption, Economic Growth, Population, Poverty and Forest Area: Evidence from Panel Data Analysis. IJEEP 2017, 7, 99-106.

76. Nepal, P.; Korhonen, J.; Prestemon, J.P.; Cubbage, F.W. Projecting Global and Regional Forest Area under the Shared Socioeconomic Pathways Using an Updated Environmental Kuznets Curve Model. Forests 2019, 10, 387. [CrossRef]

77. Huang, C.H.; Kronrad, G.D. The cost of sequestering carbon on private forest lands. For. Policy Econ. 2001, 2, 133-142. [CrossRef]

78. Im, E.H.; Adams, D.M.; Latta, G.S. Potential impacts of carbon taxes on carbon flux in western Oregon private forests. For. Policy Econ. 2007, 9, 1006-1017. [CrossRef]

79. Barbier, E.B.; Tesfaw, A.T. Can REDD+ save the forest? The role of payments and tenure. Forests 2012, 3, 881-895. [CrossRef]

80. IPCC. Climate Change 2007: The Physical Science Basis: Intergovernmental Panel on Climate Change; Agenda; United Nations Framework Convention on Climate Change: Geneva, Switzerland, 2007; p. 333.

81. Laurance, W.F. Lessons from research for sustainable development and conservation in Borneo. Forests 2016, 7, 314. [CrossRef]

82. Rahman, A.; Zulkarnain, M.; Bakar, A.; Afif, M.; Razak, K.A.; Rasib, A.W.; Kanniah, K.D.; Kadir, W.H.W.; Omar, H.; Faidi, A.; et al. Non-destructive, laser-based individual tree aboveground biomass estimation in a tropical rainforest. Forests 2017, 8, 86. [CrossRef]

83. Kindermann, G.; Obersteiner, M.; Sohngen, B.; Sathaye, J.; Anadarko, K.; Rametsteiner, E.; Schlamadinger, B.; Wunder, S.; Beach, R. Global cost estimates of reducing carbon emissions through avoided deforestation. Proc. Natl. Acad. Sci. USA 2018, 105, 10302-10307. [CrossRef] [PubMed]

84. Galante, M.V.; Dutschke, M.; Patenaude, G.; Vickers, B. Climate change mitigation through reduced-impact logging and the hierarchy of production forest management. Forests 2012, 3, 59-74. [CrossRef]

85. Pirker, J.; Mosnier, A.; Nana, T.; Dees, M.; Momo, A.; Muys, B.; Kraxner, F.; Siwe, R. Determining a Carbon Reference Level for a High-Forest-Low-Deforestation Country. Forests 2019, 10, 1095. [CrossRef]

Publisher's Note: MDPI stays neutral with regard to jurisdictional claims in published maps and institutional affiliations.

(C) 2020 by the authors. Licensee MDPI, Basel, Switzerland. This article is an open access article distributed under the terms and conditions of the Creative Commons Attribution (CC BY) license (http://creativecommons.org/licenses/by/4.0/). 